\title{
PENINGKATAN PROFESIONALISME GURU EKONOMI DALAM PEMBELAJARAN DI SMA KABUPATEN SEMARANG
}

\section{PROFESSIONALISM IMPROVEMENT OF ECONOMIC TEACHERS IN LEARNING IN SEMARANG DISTRICT HIGH SCHOOL}

\author{
${ }^{1)}$ Sriyanto, ${ }^{2)}$ Indri Murniawaty, ${ }^{3)}$ Ita Nuryana, ${ }^{4)}$ Ismiyati \\ ${ }^{1)}$ Universitas Muhammadiyah Purwokerto \\ Jl. Raya Dukuh Waluh PO Box 202 Purwokerto \\ ${ }^{2)}$ Fakultas Ekonomi Universitas Negeri Semarang \\ Jl. Sekaran Raya, Sekaran, Gn. Pati, Kota Semarang, Jawa Tengah \\ email : sriyanto1907@gmail.com
}

\begin{abstract}
ABSTRAK
Mutu pendidikan yang berkualitas dipengaruhi oleh kualitas pembelajaran, untuk itu guru dituntut mempunyai kualifikasi dan kompetensi guna meningkatkan profesionalisme guru sehingga mampu meningkatkan kualitas pembelajaran. Kompetensi pedagogik merupakan salah satu aspek kompetensi yang maтри melakukan tindakan reflektif untuk peningkatan kualitas pembelajaran antara lain dengan penelitian tindakan kelas. PTK dilakukan guru dalam rangka memperbaiki kualitas pembelajaran di kelasnya.Namun kenyataan di lapangan, masih kurangnya jumlah guru yang melaksanakan PTK, karena keterbatasan kemampuan dan pengalaman penelitian para guru. Oleh karena itu dalam kegiatan pengabdian ini diadakan pelatihan dan pendampingan untuk meningkatkan pemahaman dan kemampuan dalam melaksanakan PTK.Mitra dari kegiatan pengabdian ini adalah guru-guru yang tergabung dalam MGMP Ekonomi SMA Kabupaten Semarang. Kegiatan ini diikuti oleh 30 orang guru perwakilan dari 25 sekolah. Metode yang digunakan adalah pelatihan dan pendampingan melaksanakan penelitian tindakan kelas. Hasil evaluasi dari kegiatan ini menunjukkan bahwa $80 \%$ guru faham mengenai penelitian tindakan kelas, meskipun yang langsung mempraktekan penelitian tindakan kelas hanya $10 \%$.
\end{abstract}

Kata kunci: Profesionalisme, Penelitian Tindakan Kelas, Guru MGMP Ekonomi SMA

\begin{abstract}
The best quality of education is affected by the quality of learning, and teachers are required to have qualifications and competencies to enhance the professionalism of teachers so as to improve the quality of learning. Pedagogic competence is one of the aspect competencies that are able to take reflective actions for the improvement of the learning quality, among others, with classroom action research. Classroom action research is conducted by teachers to improve the quality of learning in their class. But in the reality, there is still a lack of teachers who implement classroom action research because of the limited ability and research experience of the teachers. Therefore, training and mentoring activities were held in this devotion to improve understanding and ability in carrying out classroom action research. Partners from this devotion activity are teachers of high school who are members of MGMP in Semarang Regency. This activity was attended by 30 representative teachers from 25 schools. The method used is training and mentoring to carry out classroom action research. Evaluation results from this activity show that $80 \%$ of teachers understand classroom action research, even though only $10 \%$ of teachers directly practice classroom action research.
\end{abstract}

Keywords: Professionalism, Classroom Action Research, High School Economics Teacher 
Sriyanto, Indri Murniawaty, Ita Nuryana, Ismiyati

Peningkatan Profesionalisme Guru Ekonomi Dalam Pembelajaran Di SMA Kabupaten Semarang

Submitted:19 September 2018 Revision:25 September 2018 Accepted:4 Oktober 2018

\section{PENDAHULUAN}

Pendidikan merupakan bentuk perwujudan kebudayaan yang dinamis, perubahan dan perkembangan dalam ilmu dan budaya memberikan dampak berubahnya pendidikan. Perubahan dalam perbaikan bidang pendidikan sudah selayaknya dilakukan sebagai persiapan menjawab semua tantangan kehidupan di masa depan. Kualitas pendidikan berkaitan dengan proses pembelajaran yang dipengaruhi banyak faktor, diantaranya kurikulum, proses pembelajaran, sarana prasarana pembelajaran, tenaga kependidikan serta manajemen sekolah. Salah satu faktor penting dalam pendidikan formal adalah guru. Di tangan gurulah hasil pembelajaran sebagai salah satu indikator mutu pendidikan lebih banyak ditentukan. Tanpa guru yang profesional, mustahil suatu sistem pendidikan dapat mencapai hasil sebagaimana diharapkan. Oleh karena itu, prasyarat utama yang harus dipenuhi bagi berlangsungnya proses belajar mengajar (PBM) yang menjamin optimalisasi hasil pembelajaran adalah tersedinya guru dengan kualifikasi dan kompetensi yang mampu memenuhi tuntutan tugasnya (Kunandar, 2011).

Peraturan Menteri Pendidikan Nasional No 16 tahun 2009 mengenai Standar Kompetensi Guru menyatakan bahwa guru harus memiliki empat kompetensi utama yaitu kompetensi pedagogik, kompetensi kepribadian, kompetensi sosial, dan kompetensi profesional. Salah satu aspek kompetensi kompetensi pedagogik adalah guru mampu melakukan tindakan reflektif untuk peningkatan kualitas pembelajaran antara lain dengan penelitian tindakan kelas.

Mengapa guru perlu melakukan penelitian ? Karena tugas guru tidaklah hanya mengajar, namun harus mengembangkan diri dan menjadikan pembelajaran menjadi lebih berkualitas. Salah satu cara untuk mewujudkannya adalah dengan meneliti. PTK sangat kondusif untuk membuat guru menjadi peka dan tanggap terhadap dinamika pembelajaran di kelasnya. Para guru menjadi reflektif dan kritis terhadap apa yang ia dan muridnya lakukan. Guru juga mampu memperbaiki proses pembelajaran mellaui suatu kajian yang dalam terhadap permasalahan di kelasnya. PTK menuntut guru untuk melakukan inovasi sebagai implementasi dan adaptasi berbagai teori dan teknik pembelajaran serta bahan ajar yang dipakainya.

Sejalan dengan UU Nomor 14 tahun 2005 tentang guru dan dosen. UU ini, disusul dengan Peraturan Pemerintah Nomor 19 tahun 2006 tentang standarisasi pendidikan. Menteri Negara Pendayagunaan Aparatur Negara juga mengeluarkan Peraturan Pemerintah. PP dimaksud, yakni Peraturan Nomor 16 tahun 2009 tentang Jabatan Fungsional Guru dan Angka Kreditnya.Penelitian Tindakan Kelas (PTK) merupakan kegiatan nyata yang dilakukan guru dalam rangka memperbaiki kualitas pembelajaran di kelasnya. Penelitian tindakan kelas dipandang sebagai bentuk penelitian peningkatan kualitas pembelajaran yang paling tepat karena selain sebagai peneliti guru juga bertindak sebagai pelaksana pembelajaran sehingga faham betul terhadap permasalahan yang dihadapi serta kondisi yang ingin dicapai. Secara ringkas, PTK dimulai dari tahap perencanaan setelah ditemukannya masalah dalam pembelajaran, dilanjutkan dengan pelaksanaan tindakan, pengamatan, dan refleksi.

Penelitian Tindakan Kelas (PTK) dilakukan sebagai upaya pemecahan masalah dan peningkatan mutu di berbagai 
bidang. Bermula ditujukan untuk mencari solusi terhadap masalah sosial (pengangguran, kenakalan remaja, dan lainlain) yang berkembang di masyarakat pada saat itu. Penelitian ini diawali suatu kajian terhadap masalah secara sistematis, observasi dan evaluasi dilakukan dalam proses yang nantinya memberikan masukan untuk melakukan refleksi. Hasil dari refeksi kemudian melandasi upaya perbaikan dan penyempurnaan rencana tindakan berikutnya. Tahapan-tahapan di atas dilakukan berulangulang dan berkesinambungan sampai suatu kualitas keberhasilan tertentu dapat tercapai. Beberapa pertanyaan yang dapat diajukan guna menuntut pelaksanaan tahapan PTK adalah sebagai berikut ini : (1) Apa yang memprihatinkan dalam proses pembelajaran?(2)Mengapa hal itu terjadi dan apa sebabnya?(3)Apa yang dapat dilakukan dan bagaimana caranya mengatasi keprihatinan tersebut?(4)Bukti-bukti apa saja yang dapat dikumpulkan untuk membantu mencari fakta apa yang terjadi?(5)Bagaimana cara mengumpulkan bukti-bukti tersebut?

Dengan melaksanakan tahap-tahap Penelitian Tindakan Kelas, guru dapat menemukan solusi dari masalah yang timbul di kelasnya sendiri, bukan kelas orang lain, dengan menerapkan berbagai ragam teori dan teknik pembelajaran yang relevan secara kreatif. Selain itu sebagai penelitian terapan, disamping guru melaksanakan tugas utamanya mengajar di kelas, tidak perlu harus meninggalkan siswanya. Penelitian ini mengangkat masalah-masalah aktual yang dihadapi oleh guru di lapangan.

Namun kenyataan di lapangan, masih kurangnya jumlah guru yang melaksanakan PTK. Hal ini dikarenakan keterbatasan kemampuan dan pengalaman penelitian para guru. Masih banyaknya kekeliruan yang dilakukan guru dalam pelaksanaan PTK, berkaitan erat dengan pemahaman mereka terhadap praktik penelitian itu sendiri, baik berkaitan dengan penyusunan proposal, pelaksanaan, maupun pelaporannya. Disamping itu, hasil-hasil penelitian yang sudah ada pun masih belum mencerminkan PTK yang sebenarnya.

Permasalahan yang dialami oleh para guru MGMP Ekonomi di Kabupaten Semarang, yaitu : 1)Kurang pemahaman mengenai Penelitian Tindakan Kelas, 2) Kesulitan dalam penulisan dan laporan Penelitian Tindakan Kelas, 3) Membutuhkan pendamping dalam pelaksanaan Penelitian Tindakan Kelas.

Berdasarkan pada analisis situasi dan kebutuhan yang disampaikan oleh para guru ekonomi yang terhimpun di MGMP-Ekonomi SMA di Kabupaten Semarang mengenai pengembangankompetensi terkait penelitian tindakan kelas maka dipandang perlu adanya pendampingan dan pelatihan untuk meningkatkan pemahaman dan kemampuan dalam melaksanakan Penelitian tindakan kelas. Pelatihan dan pendampingan ini ditujukan untuk meningkatkan kompetensi terkait pemahaman, penulisan proposal dan laporan penelitian tindakan kelas khususnya guru mata pelajaran ekonomi SMA di Kabupaten Semarang.

\section{METODE KEGIATAN}

Kegiatan pengabdian kepada
masyarakat berupa pelatihan dan
pendampingan kompetensi Penelitian
Tindakan Kelas kepada Guru mata Pelajaran
Ekonomi SMA/MA yang terhimpun dalam
Musyawarah Guru Mata Pelajaran Ekonomi
(MGMP-Ekonomi) di kabupaten Semarang
dilakukan dengan metode ceramah/panel,
tanya jawab, diskusi, penyusunan proposal
serta pendampingan. Sasaran dari kegiatan
pengabdian ini adalah semua guru mata
pelajaran Ekonomi yang direncanakan akan

JPPM ISSN: 2549 - 8347 (Online) ISSN: 2579 - 9126 (Print) Vol. 2 No. 2 September 2018 
diikuti oleh 65 orang guru SMA Ekonomi Negeri dan Swasta di Kabupaten Semarang. Partisipasi mitra dilakukan dengan cara mengikuti pelatihan peningkatan kompetensi mengenai penelitian tindakan kelas dengan sistem mendengarkan paparan terkait penelitian yang ditujukan untuk memberikan wawasan para guru mengenai penelitian, kemudian pemberian materi tentang teori dan konsep penelitian tindakan kelas, dan dilanjutkan dengan penyusunan proposal Penelitian Tindakan Kelas. Setelah pemberian materi dan penyusunan modul selesai dilaksanakan selanjutnya akan dilaksanakan pendampingan berupa fasilitas konsultasi bagi para guru yang masih kesulitan atau mendapatkan kendala dalam pelaksanaan penelitian tindakan kelas dan evaluasi keberhasilan kegiatan pelatihan dan pendampingan dengan indikator pencapaiannya adalah proposal PTK.

\section{HASIL DAN PEMBAHASAN}

Kegiatan Pelatihan Penelitian Tindakan Kelas (PTK) ini diikuti oleh 30 orang guru yang merupakan perwakilan dari Guru mata pelajaran Ekonomi dari SMA Negeri ataupun swasta yang tersebar di Kabupaten Semarang. Semua peserta pelatihan PTK antusias mengikuti semua kegiatan. Terbukti lebih dari 50\% sekolah di Kabupaten Semarang mengikuti kegiatan ini. Adapun kegiatan ini dilaksanakan di Ruang Serbaguna SMAIslam Sudirman Ambarawa. Sesuai dengan rancangan kegiatan yang direncakan, tahapan pelaksanaan kegiatan pengabdian pada masyarakat ini dilaksanakan pada tiga tahapan.Kegiatan pertama dilaksanakan pada tanggal 26 Juli 2018, berupa penyampaian dan diskusi mengenai materi Penelitian Tindakan Kelas, mulai dari menyamakan persepsi mengenai Penelitian
Tindakan Kelas dan perbedaannya dengan penelitian lain, Karakteristik PTK,penulisan proposal, teknik pelaksanaan PTK dan penyusunan laporan PTK. Tim pengabdi dan peserta guru juga menganalisis proposal PTK yang sudah dibawa sebelumnya oleh sebagian peserta. Sehingga peserta tidak hanya mendengarkan paparan materi, tetapi juga melalui studi kasus langsung. Dalam kegiatan ini pelaksana pengabdian juga memotivasi para guru untuk tertarik dan mau melaksanakan PTK, karena PTK sangat memberikan kontribusi terhadap pengembangan, perbaikan dan kemajuan pembelajaran ataupun karir guru. Dalam kegiatan ini semua peserta antusias mengikuti kegiatan, terbukti dengan banyaknya peserta yang mengajukan pertanyaan terkait Penelitian tindakan Kelas.

Kegiatan kedua guru mempraktekkan penulisan proposal dan melaksanakan PTK di sekolah masingmasing. Pemantauan kepada guru dilaksanakan dengan telepon, WA dan email. Dari hasil pemantauan hanya bebrapa guru saja yang memberikan respon.Kegiatan ketiga tanggal 30 Agustus 2018, kegiatan ini merupakan evaluasi penyusunan proposal yang sudah disusun oleh para guru serta pelaksanaan Penelitian Tindakan Kelas. Pada kegiatan semua peserta guru hadir, dari peserta yang hadir hanya 12 orang yang membawa draft proposal Penelitian Tindakan Kelas dan dua orang guru sedang melaksanakan penelitian.

Pengembangan profesionalisme guru haruslah menjadi agenda penting bagi guru itu sendiri, lembaga (sekolah) dan lebih luas lagi instansi terkait yang peduli terhadap pengembangan pendidikan di Indonesia. Para guru sebenarnya selalu bersemangat dalam pengembangan 
profesionalismenya, hal ini terbukti dengan banyaknya guru yang mau mengikuti pelatihan penulisan PTK yang dilaksanakan oleh Tim Pengabdi.

Pelaksanaan Pelatihan PTK memberikan catatan penting baik bagi guru dan tim pengabdi, pertama terkait pemahaman para guru mengenai PTK, sebenarnya para guru sudah pernah mengetahui bahkan melaksanakan Penelitian Tindakan Kelas. Untuk tahap pra penelitian guru masih merasa kesulitan dalam menentukan masalah yang dapat dijadikan bahan dalam penelitian tindakan kelas. Hal ini memberikan gambaran bahwa guru belum memahami mengenai permasalahan dalam penelitian. Penentuan bidang fokus masalah merupakan langkah awal yang paling penting dalam penelitian tindakan. Syaodih (2010) mengatakan bahwa penentuan kajian masalah merupakan hal urgen dalam penelitian tindakan kelas, dimana pemilihannya harus mempertimbangkan urgensi dan manfaat fokus dilihat sumbangannya terhadap pembelajaran. Untuk itu dalam kegiatan pelatihan, tim pengabdi memberikan konsep masalah dalam penelitian serta sumber yang dapat dijadikan masalah dalam PTK.

Kedua, pada tahap realisasi tindakan para guru tidak mengalami kesulitan, karena sudah biasa melaksanakan seperti menentukan bahan ajar, rencana pengajaran, membuat instrumen evaluasi dan melaksanakan pembelajaran, hanya saja untuk tahapan kolaboratif ada sebagian guru yang masih tidak berkenan dalam proses mengajar diamati oleh observer, meskipun observer merupakan rekan sejawatnya. Untuk itu tim pengabdi memberikan pemahaman kepada para guru bahwa peran team/observer bukan mencari kesalahan tetapi untuk mengamati pembelajaran sebagai realisasi dari perencanaan tindakan yang sudah disusun.

Ketiga, keterbatasan waktu para guru merupakan masalah utama dalam Penelitian Tindakan Kelas. Para guru mengeluhkan bahwa tugas yang banyak selain mengajar, seperti menyusun administrasi pembelajaran, pendamping/ pembina kegiatan, pengembangan profesionalisme lainnya, melanjutkan study ke jenjang S2/S3, menduduki jabatan tertentu di sekolah, anggapan bahwa hanya guru berstatus ASN (Aparatur Sipil Negara) saja yang diharuskan melaksanakan Penelitian tindakan Kelas karena berhubungan dengan kenaikan jabatan fungsional menjadikan penghambat melaksanakan Penelitian Tindakan Kelas. Dalam hal ini, tim pengabdi memberikan motivasi kepada para guru, merubah paradigma bahwa melaksanakan Penelitian Tindakan Kelas adalah keharusan, terlepas apakah guru tersebut seorang ASN atau bukan. Karena tujuan dari PTK adalah untuk menemukan solusi dari permasalahan yang terjadi selama pembelajaran dan dimungkinkan sekali ujungnya menemukan satu model pembelajaran yang dapat menjadi formula dalam pembelajaran selanjutnya.

Keempat, kendala lain dalam Penelitian Tindakan Kelas adalah penulisan Proposal dan Laporan Penelitian Tindakan Kelas. Para guru mengeluhkan sulit sekali untuk memulai menulis. Untuk itu Tim Pengabdi memberikan saran untuk mencoba menulis setiap hari meskipun hanya satu paragraf, tapi berlangsung dilaksanakan secara konsisten.

Sebenarnya, kunci utama dari melaksanakan Penelitian Tindakan Kelas bagi para guru adalah adanya kemauan dan cerdas dalam mengelola waktu dan tugas. Karena tanpa disadari PTK sebenarnya 
Sriyanto, Indri Murniawaty, Ita Nuryana, Ismiyati

Peningkatan Profesionalisme Guru Ekonomi Dalam Pembelajaran di SMA Kabupaten Semarang

kegiatan yang seringkali dilaksankan oleh guru hanya saja tidak terorganisir seperti tahapan dalam PTK.Seringkali guru menemukan kejanggalan dalam pembelajarannya, dan mencoba mencari solusi untuk mengatasinya, misalnya saja dengan menggunakan model pembelajaran kemudian mengamati adakah perbedaan dari pembelajaran sebelumnya.

Kegiatan pengabdian ini memberikan kontribusi kepada guru, baik itu perubahan pada tingkat kepahaman mengenai Penulisan Tindakan Kelas para guru ataupun pada paradigma berpikir dan sangat memotivasi para guru untuk melakukan penelitian tindakan kelas. Setelah kegiatan tahap satu banyak peserta yang berkomunikasi baik itu melalui wa, telepon atau email untuk berdiskusi mengenai Penelitian Tindakan Kelas.

\section{SIMPULAN}

Kegiatan pengabdian kepada masyarakat mengenai Pelatihan Penelitian Tindakan Kelas bagi Guru SMA mata pelajaran Ekonomi se Kabupaten Semarang telah berjalan dengan baik dan diikuti dengan sangat antusias oleh semua peserta, terbukti dengan kehadiran peserta yang selalu hadir dan mengikuti pelatihan dari awal sampai akhir kegiatan dengan penuh semangat.

Kegiatan pelatihan ini dapat
meningkatkan kompetensi guru dalam
melakukan penelitian dan memberikan
manfaat dalam kemajuan pendidikan.Salah
satu peningkatan profesionalisme melalui
pelaksanaan Penelitian Tindakan Kelas
diharapkan dapat menjadi agenda penting
bagi setiap praktisi pendidikan. Pelatihan ini
memberikan dampak yang sangat positif bagi
para guru sehingga ke depannya para guru
lebih termotivasi untuk melaksanakan

Penelitian Tindakan Kelas sampai menulisnya dalam Karya Tulis Ilmiah

\section{DAFTAR PUSTAKA}

Joni, T.R. (1998). Penelitian Tindakan Kelas. Jakarta: PCPPGSM Dirjen Dikti

Syaodih. N. (2010). Metode Penelitian Pendidikan. Bandung. Remaja Roosdakarya

Peraturan Menteri Negara Pemberdayaan Aparatur Negara Nomor 16 Tahun 2009 tentang Jabatan Angka Fungsional Guru dan Amgka Kreditnya.

Kusnandar. (2008). Langkah Mudah Penelitian Tindakan Kelas. Jakarta. Rajawali Pers 